\title{
Creating Communities: The L2 Self and ICT in an EFL Classroom
}

\author{
Daniel Ferreira \\ Ferris Women's University, Japan
}

\begin{abstract}
Developing communicative skills in English where it is a foreign language is a frustrating challenge for the L2 learner. Information and communication technologies (ICT) offer the possibility for L2 students to develop those skills collaboratively. The purpose of this article is to share the idea of building a student-centered community online where the students use the Internet as a creative space to develop their L2 identities. In this project, a first-year university class at a Japanese women's college used blogging as a space to develop and communicate their learning experience in English. A second class used video screen capture software to record a news report and then share their imagined L2 identities with the first class via the blog. By the end of term it was revealed that the learners' positive response to this project could be an instrumental approach to developing autonomous L2 communities beyond the classroom.
\end{abstract}

The continuing significance of English as a common tongue for global communication is well documented (Kirkpatrick, 2007, 2011; Ryan, 2006, 2009; Seidlhofer, 2004). Although the number of native speakers of English is declining, by 2050 half the world is expected to be using English to some extent (Graddol, 2003; Johnson, 2009). This prediction is due in large part to the continuing dominant role that English plays in the areas of science and technology, international / local business, and global communications. With the push towards globalization, the need for communicating in English has influenced many national educational policies to develop teaching methods to address that need.

A pedagogical approach to teaching English to non-native speakers in an EFL (English as a Foreign Language) environment is challenging. Unlike the ESL (English as a Second Language) setting, the EFL environment outside the classroom does not easily reinforce nor support the development of the necessary language skills required for effective communication. Access to the target-language community is either not readily accessible or may be financially unattainable. The development of Web 2.0 technologies, along with growing access to the Internet, is bridging that gap. Preparation for communication via the Internet requires important pedagogical considerations. This project will show how the use of Information and communication technology (ICT) tools can be balanced with a theoretical framework that considers the following: imagined communities, the L2 self-motivational system, and ICT in education.

Language Education in Asia, 2013, 4(1), 88-98. http://dx.doi.org/10.5746/LEiA/13/V4/I1/A7/Ferreira 


\section{Theoretical Framework}

The following section discusses three theoretical concepts that are instrumental to creating a stimulating framework for EFL students to develop their skills using Web 2.0 technologies.

\section{Imagined Communities}

Discussions of group dynamics in relation to how they affect learner motivation have tended to focus on the immediate classroom environment in which learning takes place (Dörnyei \& Murphey, 2003). Arguably, learning concerns not just the acquisition of language skills but the engagement with others who share in the same "situated learning" context (Lave \& Wenger, 1991). Anderson (1991) coined the term "imagined communities" to explain how national identity can give one the sense of belonging with those they have yet to meet and are removed from in space and time. Kanno and Norton (2003) call for a broader understanding of community that includes others who are "not immediately tangible and accessible, with whom we connect through the power of the imagination" (p. 241).

Helping learners to imagine that they are part of a larger worldwide EFL network that goes beyond the space of the classroom is an important step to increasing their motivation to learn the necessary language skills they will need to communicate with an imagined community. Wenger (1999) points out that the power of imagination can be instrumental in transcending space and time to open up new worlds for learners. Instructors can assist the learners in the "learning trajectory" needed to reach out to a transnational global community that is "no less real than those in which the learners have daily engagement and might even have a stronger impact on their current actions and investment" (Kanno \& Norton, 2003, p. 242).

\section{L2 Self-Motivational System}

The link between language identity in the foreign language context and motivation has been understood in L2 research for over 50 years (Gardner, 2001; Gardner \& Lambert, 1972). While English remains the dominant language for globalization, the traditional concept that learners' motivation for learning the language is integration with "the norm-developing inner circle countries" may not be entirely accurate (Ryan, 2006, p. 42). Lamb (2004) found that Indonesian learners associated English more with international culture than with any community bound by geographical location. Similarly, Ryan (2009) observed that Japanese students rated their reasons for studying English higher when the target culture was left "undefined" (p. 131). These studies present an important shift in our re-evaluation of the L2 self as a motivational system and how our learners identify with their sense of belonging in a global community. Perhaps what is really intrinsic to EFL students' motivation in learning English is the opportunity it affords them to restructure "a sense of who they are and how they relate to the social world" (Norton, 2000, p. 444).

Dörnyei and Csizer (2002) observe that L2 learners narrow the gap between the imagined self and the real self the more they engage in creative scenarios using the language. Research has also shown that another distinction known as the "ought-to self" controls against negative outcomes as the learners integrate their new identity into the present (Taguchi, Magid, \& Papi, 2009). The role for the teacher is to help make imagined communities accessible for learners. Learners can then practice linking new words and honing new language skills through the creation of "possible selves," as well as reaffirm and redefine their already existing L2 selves (Ryan, 2009). 


\section{ICT in Education}

The popularity of using Web 2.0 technologies for language learning is due in large part to the creation of new social spaces where learners can interact with each other. Vygotsky's claim that human beings learn through the manipulation of tools and verbal interaction with others supports the use of such technology for cognitive and social development (Erben, Ban, \& Castaneda, 2008). However, it must be remembered that success with ICT tools in a languagelearning environment is largely dependent on the proper scaffolding of its use. Although the introduction of new technologies can be frustrating for some learners, the CALL (computerassisted language learning) setting is a perfect opportunity for encouraging a collaborative environment where more proficient users of technology can assist novices to overcome difficulties. Allowing for "technology tinker time" (Erben et al., 2008, Teaching Tip 1 section, para. 1), becomes a metaphor for the trial-and-error atmosphere teachers want to foster in the classroom. Once the learners have acquired a reasonably proficient use of the tools, the teacher can take on the part of facilitator and creator of projects that stimulate the learners to apply their language skills and creativity. For example, blog sites can be set up easily so that the students can explore their L2 selves as authors and editors. According to Godwin-Jones (2006), blogs enhance students' abilities to be critical thinkers and better readers, encourage the sharing of opinions, and create an overall environment that is more student-centered.

\section{The Project: Bringing Two Communities Together}

Following the already mentioned theoretical concepts, the instructor used two CALL classrooms at the same university to experiment with ICT tools and curriculum development.

\section{Participants}

Two classes at the same women's university in urban Japan participated in this study. The participants in one class (Class A) were 36 intermediate-level first-year students enrolled in an intensive English program. The participants in the second class (Class B) were 10 students in an elective class, ranging from first to third-year. Each class met once a week for 90 minutes throughout a 15 -week term in a CALL classroom. Both classes willingly participated in sharing their work with each other online. Class objectives and a breakdown of assessments for their respective performances were explained at the start of the term.

\section{Objectives}

The objectives of the project were:

- Supporting the learners in the creation of an imagined community online through interactive blogging as suggested by the work of Kanno and Norton (2003), and

- Helping students to collaborate in the development of technological skills necessary for meaningful interaction within the community.

\section{Procedure}

Setting up the blog with Class A. Class A was expected to use a software program (with instructions in Japanese) called ALC NetAcademy 2 (ALC Education, 2013) to develop their receptive (reading and listening) skills in order to improve their TOEIC scores. The reading material is not authentic and is graded according to the level that the student chooses. Since the software does not challenge the students to improve their productive skills, supplementary tasks using inspirational TED.com videos, e.g., The 3 A's of Awesome (Pasricha, 2010), were also assigned to encourage learners to reflect on authentic, meaningful content and practice fluency in writing blogs. Every week, the students had to write a response to blog questions related to the use of ALC NetAcademy and the TED.com video materials for that week (see Appendix). Video screen capture software called Snagit (TechSmith, 2013) was used to record 
the instructor's responses to each student's blog entries, and all the recordings were assembled into one playlist (see http://www.screencast.com/help/tutorial.aspx?id=301). Figure 1 is a sample of what students see in a browser when they click on the link to the playlist. Students are not required to register for an account to see the playlist.

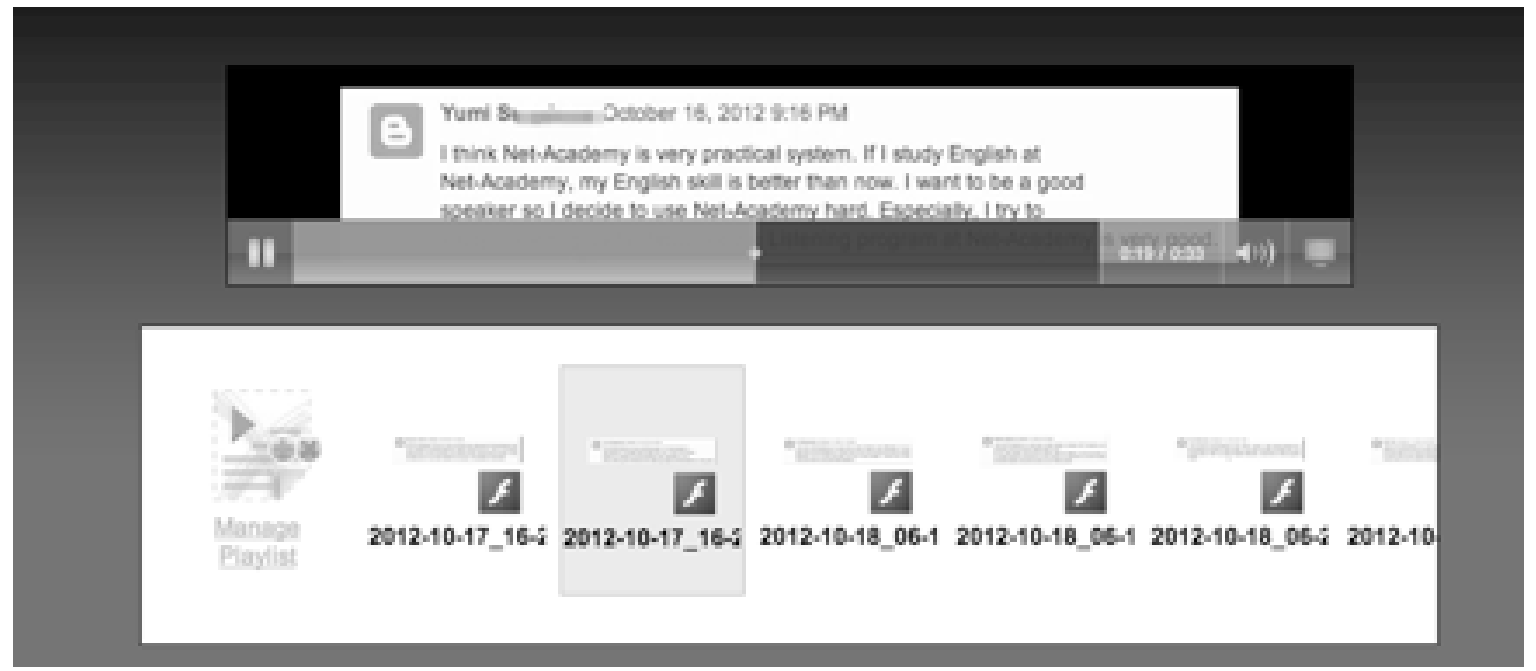

Figure 1. A playlist of the teacher's video screen captured recordings, responding to individual student blog entries.

The hyperlink link to the playlist was included in the following week's blog homework assignment (see Figure 2).

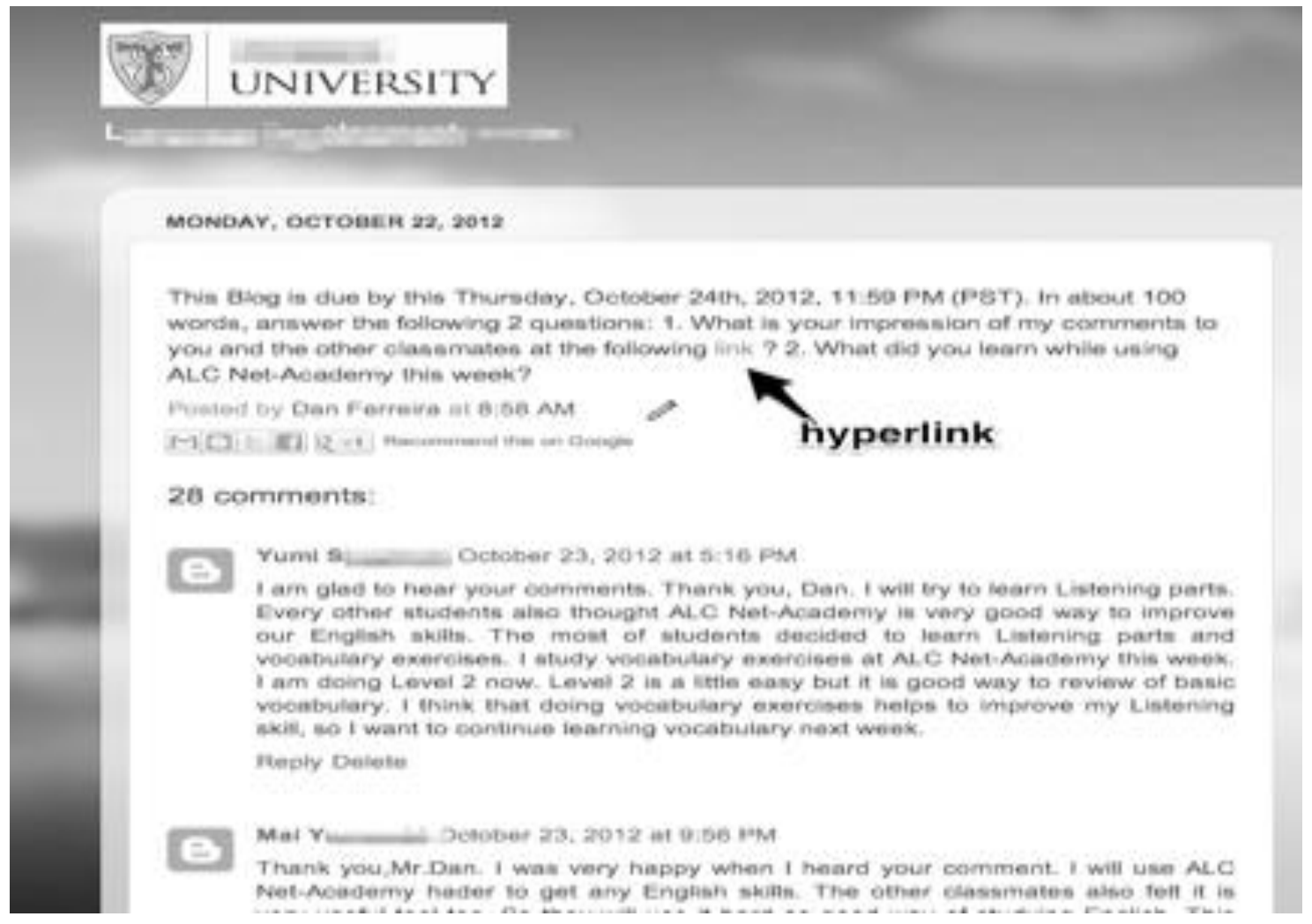

Figure 2. A blog homework post including a hyperlink to a video screencast playlist. 
Eventually, as the students became more adept at using the blog site, they were asked to listen to the instructor's comments on their classmates' blog entries and remark on any aspect that resonated with their own learning experience. This was the first stage of creating the community-like experience online. Figure 3 illustrates the initial set-up of the online blogging community.

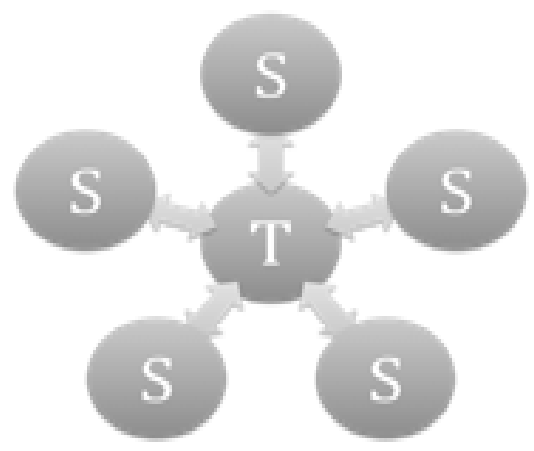

Figure 3. The first stage of creating the blogging community.

The " $\mathrm{T}$ " at the center of Figure 3 represents the teacher-fronted approach of posting the single weekly blog post. Creating one blog thread centralized students' access to each other's posts for that week. The two-way arrow between " $\mathrm{T}$ " and " $\mathrm{S}$ " illustrates the interaction between the teacher and each student. Although this first stage of creating on online community is somewhat teacher-centered, the instructor really serves as a conduit to the other class members due to the playlist feature (Figure 1) of sharing each other's blogs. More specifically, the students have access to each other's work, and the interaction takes place on a blog thread for all to share and comment on.

The newscast video screen capture with Class B. Class B, the other class of 10 students in an elective course focusing on news media English, engaged in activities that prepared them to work with news media texts and videos. Students were introduced to the idea of creating a university vidcast (video podcast) online for the following Fall semester. It was explained that the vidcast would be a bi-weekly newscast that would be controlled, produced, and presented by the students and would feature news related to campus activities and local community events in a news-style format. The students understood that their newscast recordings would be evaluated by another community of learners (i.e., Class A) on the following criteria:

- Content being adapted to the local area (preferably around the university locale)

- Creative use of PowerPoint

- Humor (one or more news items had to be humorous)

- Clear pronunciation

- Good intonation

Students were taught how to record with the Snagit video screen capture software. Each student was assigned a news item from a site called Elllo (2013) where she replaced all the content words and adapted the news content to the listed criteria (see https://vimeo.com/57753067 for a sample). This approach allowed the students to focus on the above criteria while feeling relatively confident about the grammatical aspects particular to the genre of news reporting. The teacher provided corrective feedback on the written scripts on an individual level. However, feedback on the technical aspects of the video recordings was 
shared as a whole-class activity. After the news video screencasts had been completed, two videos a week were shared and hyperlinked with the blogs of Class A as shown in Figure 4.

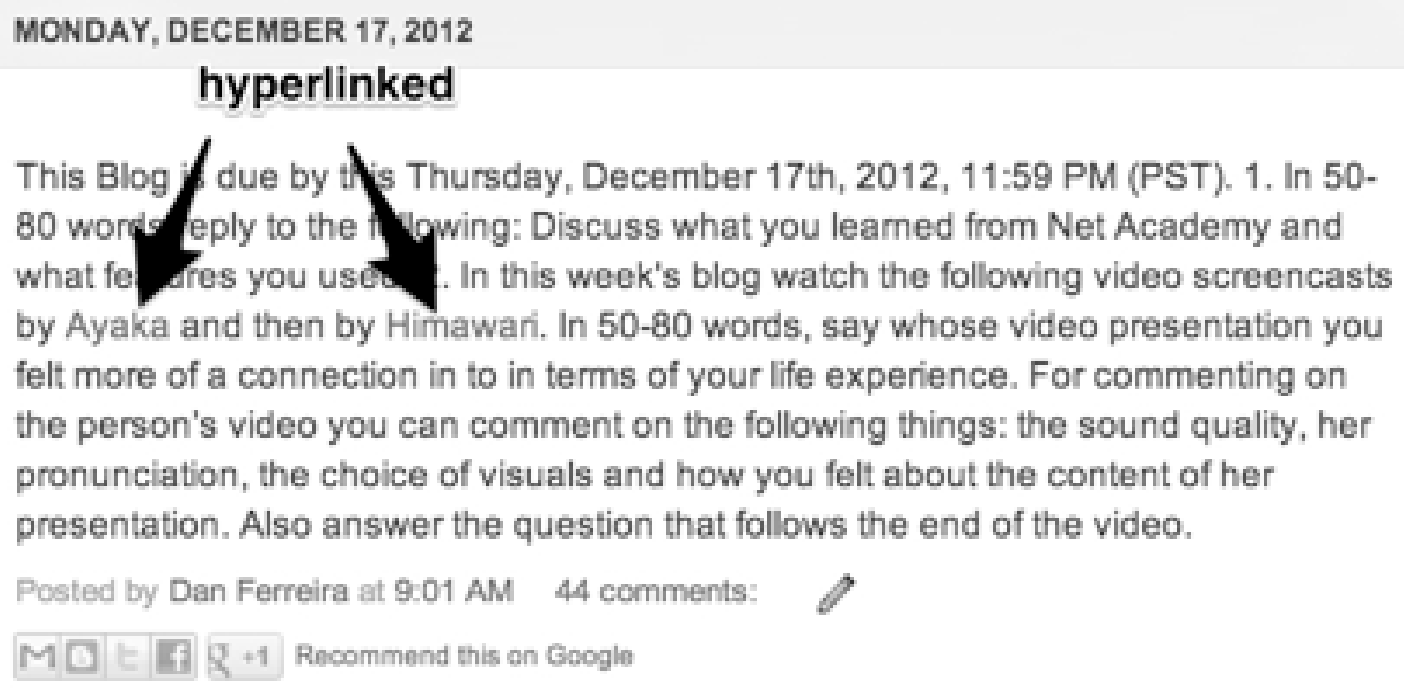

Figure 4. A sample blog assignment with hyperlinks to Class B's video screencasts.

Each student in Class A commented on the newscasts. The Class B students whose newscasts were profiled for the week were also invited to share their comments. The comments from both classes focused on the specific criteria in addition to the video production quality. By this stage, the instructor had stopped responding to the individual blogs and had become the facilitator for both classes in a new community. This second stage of the merged blogging community is illustrated in Figure 5.

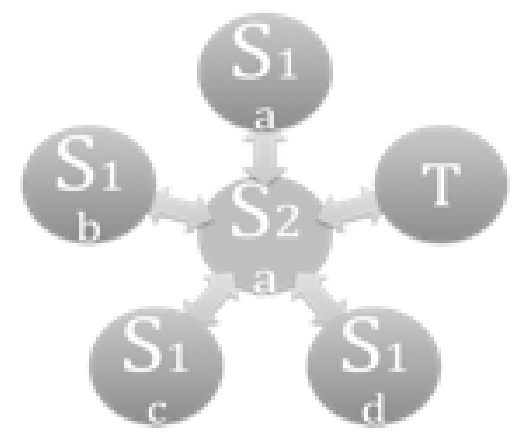

Figure 5. The blogging community becoming more autonomous in Stage Two.

In the second stage of the blogging community, a new group of students started to participate. S2a at the center represents the student from Class B who produced the newscasts, and S1a-d represent the Class A students. At this point, the teacher took the role of facilitator and coordinated the interaction between the two classes. Throughout the remaining weeks of the course for both classes, the teacher continued to provide open class feedback on submitted blogs and technical assistance to the second class in their newscast productions. 


\section{Student Evaluation}

At the end of the term, Class A chose three candidates from Class B for the role of main newscaster. A playlist of all the videos was made available for all the students to see and evaluate. Additionally, at the end of term, the students were asked to rate which of the following three components of the course inspired them the most: the video screencasts from the students of the other class, the teacher's vocal comments, or the classmates' blog entries. Of the 27 respondents, $40 \%$ chose the classmates' blogs, 33\% the screencasts of the other class, and $25 \%$ chose the teacher's vocal comments. Overall, the results show a balance of appreciation for all three contributions by the community.

\section{Discussion}

The newscast project was primarily inspired by the theoretical concept of using the imagination to create a "possible L2 self" (Dörnyei \& Csizer, 2002). However, the written communication between the two classes on the blogging site and the possibility for members of Class B to be elected as the main newscaster for the upcoming News Vidcast project in the Fall semester showed a "narrowing of the gap" between the imagined and the present L2 self (Dörnyei \& Csizer, 2002). The pace of language production in an asynchronous environment that the blogging community provided allowed the learners to self-regulate their own growth while developing and expanding their "knowledge capital" with other learners (Erben et al., 2008, Implications for the Classroom section 1, para. 1). Moreover, the learners seemed to appear to distinguish quite well between the act of language learning and using language to reaffirm their present L2 identities (Ryan, 2009).

The newscast presentations for Class B required a lot of technical support. When introducing IT (instructional technology) tools into the learning cycle, teachers have to assess where their students' abilities lie in the continuum. In Erben, Ban, and Castañeda's "nine-point continuum of IT use" (2008), video podcasting and blogging are rated as the highest skills for IT use. If students' experience with IT places them lower on the continuum, then advancing them too soon may prove to be frustrating for them. Since Class B was an elective class, student motivation and group collaboration to overcome the learning curve using the video screencasting software proved to be an advantage. Through trial and error, students were able to use the technology to creatively achieve the objective of the newscast presentation.

However, the author did face some difficulties with the newscast presentations. Since the students possessed varying ranges of ability in language and technical abilities, the following changes would be recommended for the future:

- More collaboration during class between the higher- and lower-level students in the use of technology;

- More peer support in editing written drafts for the newscast;

- More opportunities for the students to give each other feedback on their work;

- Time during class for students to practice pronunciation and spoken presentation of their drafts prior to recording; and

- More one-to-one support from the teacher for pronunciation and intonation.

\section{Conclusion}

This research has found the following results. In Stage 1 of the blogging community, students in the first-year responded well to the teacher's comments on the weekly blog posts. Although this was somewhat teacher-centered, the students were able to access each other's work thanks to the playlist feature of video screencasts. After a month of teacher feedback on individual posts 
and writing fluency assignments, the class was ready for the second stage of blogging that allowed for the introduction of a second community to participate and share their work.

Creating the community online was more than just learning language; as the students worked to control the tools for communication, they were engaging with each other and sharing knowledge and expertise. The blog site became an extension of the learning space where the learners could meet and communicate, albeit asynchronously. Class B drew inspiration from both the inter- and intra-group communication. The enthusiasm students expressed about using the technology for learning and communicating was shown in their responses on the blogs. What remains to be seen is whether this approach to using the Internet to reaffirm their L2 identity would be as successful if the Japanese learners were to engage with a community of EFL / ESL learners of a different L1 background. Moreover, it remains unclear how effective the newscast project was for preparing the students of Class B to produce their own texts for the proposed university vidcast idea. As the goal was not to focus on newscast genre writing per se, using ICT to bridge two separate classes while exploring the creation of L2 selves proved relatively successful.

It is envisaged that the ideas in this study will encourage other instructors to look at the use of ICT tools as a means for helping EFL students explore many possible L2 selves and to help the learners realize that they are part of a larger imaginable community.

\section{Author Note}

Daniel Ferreira, Department of Letters, Ferris Women's University, Yokohama, Japan.

Correspondence concerning this article should be addressed to Daniel Ferreira, Department of Letters, Ferris University, 4-5-3 Ryokuen, Izumi-ku, Yokohama, Kanagawa, Japan, 245-8650. Email: ferreira_daniel@ferris.ac.jp 


\section{References}

ALC Education Inc. (2013). アルクネットアカデミー [ALC NetAcademy]. http://www.alceducation.co.jp/academic/net/index.html

Anderson, B. (1991). Imagined communities: Reflections on the origin and spread of nationalism (Rev. ed.). London, England: Verso.

Dörnyei, Z., \& Csizer, K. (2002). Some dynamics of language attitudes and motivation: Results of a longitudinal nationwide survey. Applied Linguistics, 23(4), 421-462. http://dx.doi.org/10.1093/applin/23.4.421

Dörnyei, Z., \& Murphey, T. (2003). Group dynamics in the language classroom. Cambridge, England: Cambridge University Press. http://dx.doi.org/10.1017/CBO9780511667138

Elllo. (2013). English listening lesson library online: Mixer lessons. http://elllo.org/english/NewCenter.htm

Erben, T., Ban, R., \& Castañeda, M. (2008). Teaching English language learners through technology. New York, NY: Routledge.

Gardner, R. C. (2001). Integrative motivation and second language learning: Practical issues. Kansai University Journal of Foreign Language Education and Research, 2, 71-91.

Gardner, R. C., \& Lambert, W. E. (1972). Attitudes and motivation in second-language learning. Rowley, MA: Newbury House.

Godwin-Jones, R. (2006). Tag clouds in the blogosphere: Electronic literacy and social networking. Language Learning \& Technology, 10(2), 8-15.

Graddol, D. (2003). The decline of the native speaker. In G. Anderman \& M. Rogers (Eds.), Translation today: Trends and perspectives (pp. 152-167). Clevedon, England: Multilingual Matters.

Johnson, A. (2009). The rise of English: The language of globalization in China and the European Union. Macalester International, 22(1), 131-168. Available at http://digitalcommons.macalester.edu/cgi/viewcontent.cgi?article=1447 \&context=macin $\mathrm{tl}$

Kanno, Y., \& Norton, B. (2003). Imagined communities and educational possibilities: Introduction. Journal of Language, Identity, and Education, 2(4), 241-249. http://dx.doi.org/10.1207/S15327701JLIE0204_1

Kirkpatrick, A. (2007). World Englishes: Implications for international communication and English language teaching. Cambridge, England: Cambridge University Press.

Kirkpatrick, A. (2011). English as an Asian lingua franca and the multilingual model of ELT. Language Teaching, 44(2), 212-224. http://dx.doi.org/10.1017/S0261444810000145

Lamb, M. (2004). Integrative motivation in a globalizing world. System, 32(1), 3-19. http://dx.doi.org/10.1016/j.system.2003.04.002

Lave, J., \& Wenger, E. (1991). Situated learning: Legitimate peripheral participation. Cambridge, England: Cambridge University Press.

Norton, B. (2000). Identity, acculturation, and language loss. In S. McKay \& S. L. Wong (Eds.), English language learners in the United States: A resource for teachers (pp. 443-461). Cambridge, England: Cambridge University Press.

Pasricha, N. (2010, September 30). The 3 A's of awesome [Video file]. Retrieved from http://www.ted.com/talks/neil_pasricha_the_3_a_s_of_awesome.html

Ryan, S. (2006). Language learning motivation within the context of globalisation: An L2 self within an Imagined global community. Critical Inquiry in Language Studies: An International Journal, 3 (1), 23-45. http://dx.doi.org/10.1207/s15427595cils0301_2

Ryan, S. (2009). Self and identity in L2 motivation in Japan: The ideal L2 self and Japanese learners of English. In Z. Dörnyei \& E. Ushioda (Eds.), Motivation, Language Identity and the L2 Self (pp. 120-143). Bristol, England: Multilingual Matters. 
Seidlhofer, B. (2004). Research perspectives on teaching English as a lingua franca. Annual Review of Applied Linguistics, 24, 209-239.

http://dx.doi.org/10.1017/S0267190504000145

Taguchi, T., Magid, M., \& Papi, M. (2009). The L2 motivational self system among Japanese, Chinese and Iranian learners of English: A comparative study. In Z. Dörnyei \& E. Ushioda (Eds.), Motivation, Language Identity and the L2 Self (pp. 66-97). Bristol, England: Multilingual Matters.

TechSmith Corporation. (2013). Snagit: The Ultimate Screen Capture Tool [Software]. http://www.techsmith.com/snagit.html

Wenger, E. (1999). Communities of practice: Learning, meaning, and identity. New York, NY: Cambridge University Press. 


\section{Appendix}

\section{Sample Blog Homework Post}

This blog is due by this (Insert Date).

1. In 50-80 words, reply to the following: Discuss what you learned from Net Academy and what features you used (Reading, Listening, Vocabulary).

2. In this week's blog, watch the following video screencast: Neil Pasricha http://www.ted.com/talks/neil_pasricha_the_3_a_s_of_awesome.html In 50-80 words, say what you learned about the video presentation and how it connects to you in terms of your life experience. 